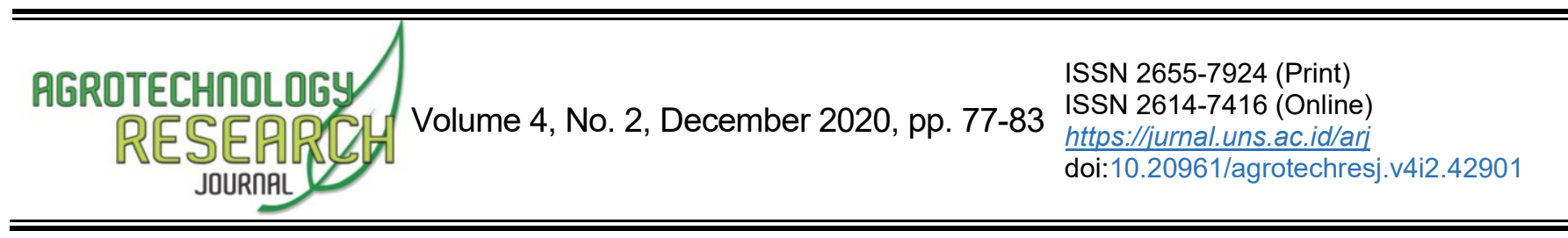

\title{
Penerapan Model Regresi Bertatar dalam Penentuan Hasil Tanaman Sorgum
}

\author{
Suwardi ${ }^{1^{*}}$, Nining Nurini Andayani ${ }^{2}$, Fahdiana Tabri ${ }^{3}$, Muhammad Aqil ${ }^{4}$ \\ ${ }^{1-4}$ Balai Penelitian Tanaman Serealia, Maros, Sulawesi Selatan, Indonesia
}

Received 13 July 2020; Accepted 18 September 2020; Published 1 December 2020

\begin{abstract}
Sorghum is one of the prospective food crops to be developed in Indonesia. High yielding sorghum variety development is carried out through a series of breeding processes, including agronomic character selection among sorghum plants. The research's objective was to examine the stepwise regression model in selecting agronomic parameters that affect the yield of sorghum grain yield. Evaluation and modeling of the relationship between agronomic parameters and sorghum yield was carried out with two varieties of sorghum, namely Super 1 and Super 2 , by using an experimental engineering approach. The estimation model based on information on the phenotypic character of sorghum was implemented using stepwise regression analysis. The results indicated that agronomic parameters affect the yield of sorghum was estimated in three stages, and the final yield equation is $Y=-3.413+$ $0.033 \times 2+0.561 \times 3+0.006 \times 5$. The variables included in the model are $\times 3$ (panicle width), $\times 5$ (plant height at harvest), and $x 2$ (panicle length). Correlation and determination coefficient values up to this stage were 0.82 and 0.68 , respectively. This indicates that sorghum production can be optimized by the three significant variables: viz, panicle width, plant height at harvest, and panicle length. These results can then be used as a basis for selecting varieties to obtain high yield potential varieties.
\end{abstract}

Keywords: Agronomic traits; Evaluation; Varieties

Cite This As (CSE Style): Suwardi, Andayani NN, Tabri F, Aqil M. 2020. Penerapan Model Regresi Bertatar dalam Penetuan Hasil Tanaman Sorgum. Agrotech Res J. 4(2): 77-83. https://doi.org/10.20961/agrotechresj.v4i2.42901.

\section{PENDAHULUAN}

Sorgum merupakan salah satu komoditas pangan yang mempunyai kandungan gizi yang tinggi. Pengembangan komoditas sorgum menghadapi beberapa kondisi, misalnya curah hujan rendah dan eratik, tanaman masih dapat tumbuh dan memberikan nilai tambah bagi masyarakat Kementerian Pertanian tengah menggalakkan program diversifikasi pangan berbasis pangan lokal, salah satunya dengan menggalakkan penggunaan sorgum dalam program diet pangan. Pada tahun 2020, pemerintah kembali mencanangkan program penanaman sorgum seluas 5000 ha pada sentra utama pengembangan sorgum di Nusa Tenggara Timur (NTT), Sulawesi Tenggara, Wonogiri, Gunungkidul serta wilayah potensial lainnya (Kementerian Pertanian 2020). Sorgum mempunyai kandungan unsur Fe cukup memadai $4-5,5 \mathrm{mg} / 100 \mathrm{~g}$ sehingga dapat menjadi nilai tambah sebagai bahan pangan. Unsur Fe merupakan unsur paling penting untuk pembentukan sel darah merah. Kekurangan

${ }^{*}$ Corresponding Author:

E-Mail: wardisereal@yahoo.co.id mineral seperti besi ditengarai sebagai salah satu penyebab pertumbuhan badan menjadi lambat atau sering disebut gejala stunting (Akomo et al. 2016).

Pertanaman sorgum umumnya dijumpai pada lahan kering dan lahan tadah hujan dengan curah hujan yang pendek atau tidak merata. Areal potensial untuk pertanaman sorgum sebenarnya cukup luas termasuk lahan kritis. Lahan kering dikelompokkan menjadi lahan pekarangan, tegal/kebun/ladang, padang rumput, lahan sementara tidak diusahakan, lahan untuk kayu-kayuan, dan perkebunan. Lahan kering tersebut potensial untuk pengembangan sorgum (Aqil dan Bunyamin 2013). Pada lahan kering beriklim kering dataran rendah, pola tanam sorgum-sorgum (ratun I) - bera dapat diterapkan apabila ada jaminan pengairan tanaman dari air tanah dangkal.

Pertumbuhan tanaman sorgum sangat dipengaruhi antara lain: faktor lingkungan, unsur hara, air dan intensitas cahaya matahari. Faktor-faktor tersebut mempengaruhi agronomis tanaman yang berpengaruh terhadap hasil biji sorgum. Oleh karena itu diperlukan metode analisis peranan peubah agronomis terhadap hasil biji sorgum. Aplikasi metode statistik pada morfologi tanaman yang berkorelasi dengan hasil mengharuskan adanya pemilihan model yang tepat 
karena korelasi bukan hanya karena faktor genetik semata tetapi faktor lokasi/lingkungan. Terdapat berbagai macam metode yang dapat digunakan untuk mengetahui peranan peubah agronomis terhadap tanaman diantaranya adalah dengan analisis regresi bertatar (stepwise analysis) (Weisberg 2013).

Analisis bertatar adalah prosedur memilih peubah bebas $(x i)$ yang dominan untuk dijadikan input model regresi guna menduga besaran peubah tak bebas $(y)$ pada setiap satuan ( $x i)$ Metode stepwise merupakan gabungan dari dua metode yaitu analisis penyisihan mundur (backward procedure) dan pemilihan maju (forward procedure). Model bertatar diawali dengan memasukkan peubah bebas yang mempunyai korelasi sederhana tertinggi terhadap $y$, disusul dengan menghitung koefisien korelasi parsial dan nilai tertinggi pada model regresi bertatar. Stone dan Schlegel (2006) menerapkan metode analisis parameter secara bertatar dalam menganalisis hubungan antara curah hujan lokal serta tingkat regim air terhadap pertumbuhan dan hasil tanaman sorgum di lahan kering. Model ini mampu menjelaskan $63 \%$ perubahan tingkat hasil akibat variasi curah hujan lokal. Farhood Al-salim et al. (2017) menyatakan bahwa tingkat penggunaan nitrogen dalam pemupukan tanaman sorgum berpengaruh terhadap tingkat hasil yang diperoleh. Mokashi et al. (2008) menerapkan teknik regresi bertatar dalam mempelajari hubungan antara berbagai waktu tanam terhadap tingkat hasil biji pada lima varietas sorgum. Hasil penelitian menunjukkan bahwa parameter agroklimat mempunyai pengaruh yang besar terhadap tingkat hasil yang diperoleh. Model regresi bertatar dapat menjelaskan $78 \%$ variasi hasil biji sorgum. Shoaa Hosseini et al. (2008) menguji model bertatar pada skrining jagung pada kondisi kekeringan. Parameter yang berpengaruh terhadap hasil adalah diameter tongkol, jumlah biji per baris, dan panjang tongkol berkorelasi dengan hasil.

Penelitian bertujuan untuk menganalisis pengaruh variabel pertumbuhan tanaman terhadap hasil biji sorgum menggunakan model regresi bertatar. Parameter yang berperanan selanjutnya dibuat model dalam bentuk regresi berganda, dan sebagai kajian penting dalam penerapan seleksi varietas unggul sorgum untuk pangan dan pakan.

\section{BAHAN DAN METODE}

Penelitian di laksanakan di Kebun Percobaan Balai Penelitian Tanaman Serealia, Maros Sulawesi Selatan pada bulan Agustus - November 2016 pada ketinggian tempat $15 \mathrm{~m}$ di atas permukaan laut dengan -5.310031 LS, 119.506721 BT. Evaluasi dan modeling hubungan antara parameter agronomi dengan hasil sorgum dilakukan dengan 2 varietas sorgum yaitu Super 1 dan Super 2. Varietas ini mempunyai kelebihan yaitu tinggi tanamannya di atas $2 \mathrm{~m}$ dengan potensi biomas dan bij yang tinggi. Pelaksanaan penelitian menggunakan pendekatan engineering experiment. Jarak tanam yang digunakan dalam penelitian adalah $75 \times 25 \mathrm{~cm}$ (3 biji per lubang dan penjarangan dilakukan pada umur 14 hst (hari setelah tanam). Ukuran petak $9 \mathrm{~m} \times 4 \mathrm{~m}$ dengan tiga ulangan dengan jarak antar petak 1 meter. Teknologi budidaya dan pemeliharaan tanaman mengikuti juknis yang di buat oleh Balai Penelitian Tanaman Serealia (Balitsereal 2017).

Pengamatan dilakukan pada fase vegetatif akhir, fase generatif serta fase panen. Parameter yang diamati yaitu tinggi tanaman (cm) 30 (HST) dan 105 (HST), kadar gula brix (\%) dan volume nira/batang $(\mathrm{ml})$ tiap $1 \mathrm{~kg}$ batang, jumlah ruas 105 (HST), diameter batang (cm) 75 (HST), hasil biji (t/ha) dan komponen hasil (bobot 1000 biji (g), panjang dan lebar malai (cm), bobot biomas (ha) dan klorofil daun (SPAD) 35 (HST). Data hasil penelitian diuji secara deskriptif dan dianalisis ragam dan galatnya. Uji multikolinieritas dilakukan untuk menguji adanya overfitting antara parameter model, selanjutnya dilakukan analisis regresi bertatar (stepwise regression) untuk penyaringan parameter model berbasis dropout, artinya parameter yang tidak signifikan pengaruhnya berdasarkan uji F akan dikeluarkan dari model. Analisis dilakukan dengan menggunakan perangkat lunak SPSS 14. Selanjutnya dilakukan analisis korelasi untuk mendapatkan informasi karakter agronomis dan komponen hasil tanaman.

Pendekatan analisis mengikuti tahapan regresi multivariate sebagai berikut (Fahrmeir et al. 2013; Keith 2014):

$$
\begin{aligned}
& \mathrm{Y}=\beta 0+\beta 1 \mathrm{X} 1+\beta 2 \mathrm{X} 2+\ldots+\beta \mathrm{kXk}+\varepsilon \\
& \text { dimana } \\
& \mathrm{Y}=\text { variabel dependen } \\
& \beta 0=\text { konstanta regresi } \\
& \beta 1, \beta 2, \ldots, \beta \\
& \mathrm{k}=\text { koefisien regresi } \\
& \mathrm{X} 1, \mathrm{X} 2, \ldots, \mathrm{Xk}=\text { variabel bebas } \\
& \varepsilon=\text { galat taksiran (sisa residu). }
\end{aligned}
$$

Ukuran keeratan hubungan linier antar peubah dihitung melalui korelasi sederhana antar peubah dan terhadap hasil bobot biji dengan nilai statistik uji mengikuti kaidah (Gomez dan Gomez 1984; Chatterjee dan Hadi 2006), yaitu r: $[\Sigma x y] /[\sqrt{ }(\Sigma x 2)(\Sigma y 2 \sim r(n-2), n=$ 200.

\section{HASIL DAN PEMBAHASAN}

\section{Analisis pendahuluan karakter fenotipik sorgum}

Analisis regresi bertatar untuk pendugaan hasil tanaman sorgum berdasarkan karakter fenotipiknya diakukan dengan menggunakan sistim penyaringan/skrining parameter sehingga akan dihasilkan model yang fit dengan data. Sebelum dilakukan penyaringan model, dilakukan analisis multikolinieritas terhadap parameter model. Uji Multikolinieritas bertujuan untuk menguji apakah model regresi ditemukan adanya korelasi antar variabel bebas (Independent) dalam model regresi yang dibuat. Model regresi yang baik harusnya tidak terjadi korelasi diantara variabel bebas (tidak terjadi Multikolinieritas). Jika variabel bebas saling berkorelasi, maka variabel variabel ini tidak ortogonal yaitu variabel bebas yang nilai korelasi antar sesama variabel bebas sama dengan nol (Park 2003). 
Sebanyak 10 variabel dianalisis kolinieritasnya dengan menggunakan dua kriteria yaitu VIP (Vasoactive Intestinal Peptide) dan Tolerance. Kriteria penerimaan adalah nilai Tolerance $>0,1$ dan nilai VIF (Variance Inflation Factor) $<10,00$. Hasil analisis menunjukkan bahwa dari 10 variabel tersebut, tiga diantaranya mengandung multikolinearitas yaitu parameter biomas, nilai klorofil daun Soil Plant Analysis Development (SPAD) serta tinggi tanaman pada fase vegetatif akhir. Sementara itu tujuh parameter lainnya yaitu berat 1000 biji (J1000B), panjang malai (PM), lebar malai (LM), diameter batang (DB), jumlah ruas batang (JRB), tinggi tanaman pada fase vegetatif akhir (TV) serta tinggi tanaman saat panen (TP), memenuhi syarat multikolinieritas berdasarkan nilai toleransi yang nilainya di atas batas toleransi $(>0,1)$ serta dan VIF $<10,00$ seperti dapat dilihat pada Gambar 1 dan Gambar 2. Parameter biomas, nilai klorofil daun (SPAD) serta tinggi tanaman pada fase vegetatif akhir selanjutnya dikeluarkan dari model dan parameter berat $1000 \mathrm{biji}$ (J1000B), panjang malai (PM), lebar malai (LM), diameter batang (DB), jumlah ruas batang (JRB), tinggi tanaman pada fase vegetatif akhir (TV) serta tinggi tanaman saat panen (TP), dianalisis lanjut pada pengujian model regresi bertatar/stepwise.

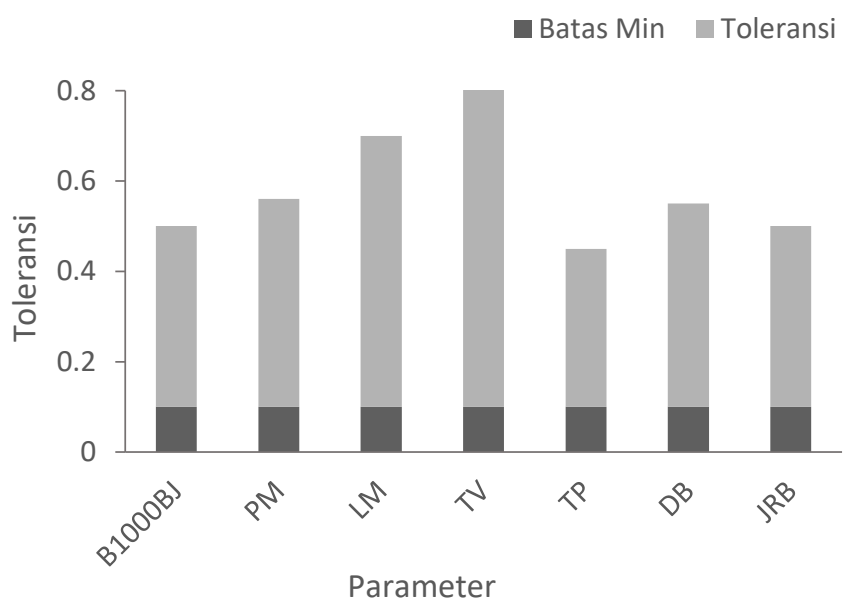

Gambar 1. Diagram batang nilai batas toleransi karakter tanaman sorgum

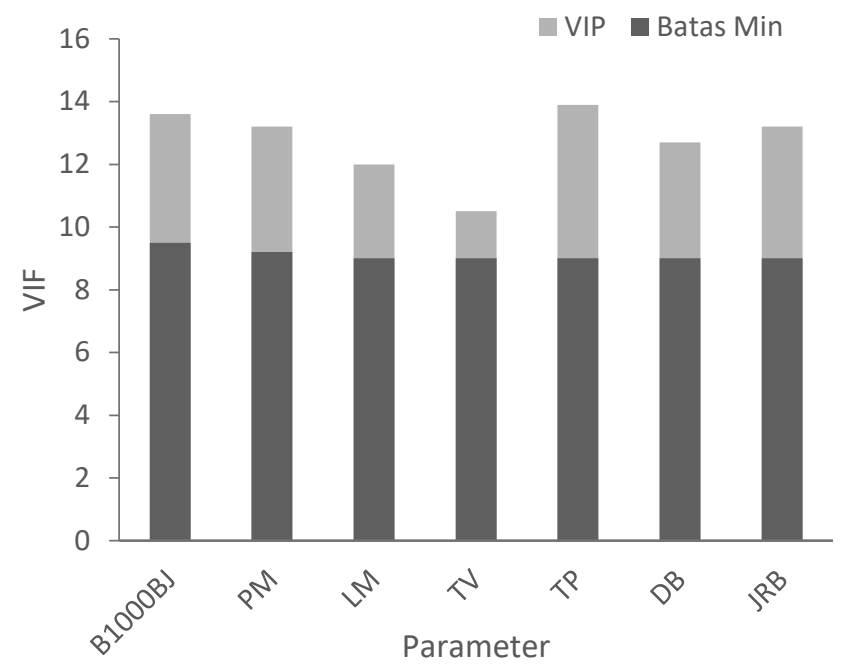

Gambar 2. Diagram batang nilai VIF karakter tanaman sorgum

Tujuh parameter fenotipik tanaman ditambah parameter hasil biji selanjutnya di analisis nilai deskriptif yang meliputi rata-rata, standar deviasi, varians, minimum, serta nilai maksimum untuk memberikan gambaran pola data yang akan dianalisis. Keakuratan data secara deskriptif akan membantu memberi arah pola inferensial dari model yang akan dikembangkan. Hasil analisis deskriptif parameter model produksi tanaman sorgum dapat dilihat pada Tabel 1. Beberapa variabel mempunyai rentang nilai yang cukup besar diantaranya variasi hasil biji (1,03-4,72 t/ha), panjang malai $(17,15-32,71 \mathrm{~cm})$, tinggi tanaman vegetatif $(34,27-$ $102,56 \mathrm{~cm}$ ). Penelitian dilakukan pada 1 lokasi/petakan, namun memiliki rentang yang cukup tinggi diduga karena lokasi penelitian mempunyai tingkat kesuburan yang berbeda serta pengaruh kadar salinitas tanah yang bervariasi antar titik pengamatan. Hal tersebut disebabkan oleh tanah timbunan baru sehingga variasi titik pengamatan cenderung mengalami perbedaan. Kelas tekstur tanah adalah liat geluhan (clay loam) dengan campuran timbunan pada bagian atas permukaan tanah yang berkontribusi terhadap variasi penampilan fenotipik tanaman (Andriani dan Isnaini 2013).

Tabel 1. Analisis deskriptif parameter model regresi bertatar

\begin{tabular}{lrrrrr}
\hline Parameter & Rata-rata & Standar deviasi & Varians & \multicolumn{1}{l}{ Minimum } & \multicolumn{1}{c}{ Maksimum } \\
\hline Bobot 1000 biji $(\mathrm{g})$ & 29,493 & 3,345 & 11,189 & 24,400 & 39,100 \\
Panjang malai $(\mathrm{cm})$ & 26,879 & 3,907 & 15,263 & 17,150 & 32,717 \\
Lebar malai (cm) & 6,154 & 0,712 & 0,507 & 4,500 & 8,000 \\
Tinggi tanaman vegetatif akhir (cm) & 67,213 & 17,904 & 320,568 & 34,267 & 102,650 \\
Tinggi tanaman saat panen (cm) & 271,828 & 34,534 & 1192,597 & 191,667 & 338,333 \\
Diameter batang (cm) & 2,178 & 0,167 & 0,028 & 1,762 & 2,622 \\
Jumlah ruas & 10,954 & 1,360 & 1,851 & 8,333 & 13,667 \\
Hasil (t/ha) & 2,433 & 0,735 & 0,541 & 1,030 & 4,720 \\
\hline
\end{tabular}




\section{Penyaringan parameter model bertatar (stepwise)}

Sebanyak tujuh parameter model (selanjutnya dinamakan $x 1-x 7$ ) disaring/skrining untuk menentukan variabel yang berperan dalam proses produksi hasil biji sorgum. Penyaringan variabel yang berpengaruh signifikan terhadap model meliputi serangkaian proses penyaringan bertatar untuk mencari variabel yang memenuhi kriteria model yang diinginkan. Pada penyaringan Tahap I diperoleh peubah yang memenuhi kriteria model adalah $x 3$ (lebar malai tanaman sorgum). Hasil ini sesuai dengan nilai korelasi parsial peubah lebar malai yaitu 0,48 . Peubah ini selanjutnya dijadikan peubah utama dalam menentukan besarnya hasil sorgum varietas Super 1 dan Super 2 (Tabel 2 dan Tabel 3). Pada saringan tahap I nilai $F$ hitung sebesar 130,650 serta signifikansi $=0,00$ (sangat nyata). Pada model regresi sederhana antara $x 3$ terhadap hasil y diperoleh nilai $R^{2}=0,60$ dan $R=0,77$. Azrai et al. (2013) menyatakan bahwa hasil biji sorgum ditentukan oleh beberapa komponen hasil diantaranya, lebar, panjang, dan bobot malai serta, hasil biji. Tesso et al. (2011) dalam penelitiannya pada tipe sorgum menemukan korelasi positif antara hasil biji dengan karakter fenotipik malai. Aksesi sorgum yang memberikan hasil biji tinggi memiliki komponen fenotipik yang tinggi pula.

Penyaringan Tahap II didapatkan peubah yang memenuhi kriteria model adalah $\times 3$ (lebar malai) serta $\times 5$ (tinggi tanaman saat panen). Tahapan ini menunjukkan bahwa dua peubah bebas yakni lebar malai dan tinggi tanaman merupakan peubah penting dalam menghasilkan sorgum berdaya hasil tinggi. Pada saringan tahap awal nilai $F$ hitung sebesar 82,17 serta signifikansi $=0,00$ (sangat nyata). Pada model regresi sederhana antara $\times 3$ terhadap hasil y diperoleh nilai $R^{2}$ $=0,81$ dan $\mathrm{R}=0,65$.
Pada saringan tahap III diperoleh peubah yang masuk dalam model secara berurut adalah $x 3$ (lebar malai), $x 5$ (tinggi tanaman saat panen) serta $\times 2$ (Panjang malai). Nilai koefisien korelasi dan determinasi sampai pada tahapan ini adalah 0,82 dan 0,68. Hal ini menunjukkan bahwa lebar malai, tinggi tanaman saat panen dan panjang malai sebagai peubah bebas yang optimal dalam produksi biji sorgum. Malai merupakan tempat produksi biji pada tanaman sorgum. Semakin besar ukuran malai semakin tinggi peluang untuk mendapatkan hasil biji yang banyak. Ukuran malai ditentukan oleh panjang dan lebar malai. Varietas unggul sorgum umumnya mempunyai tingkat produksi sampai 5 t/ha dan pada beberapa varietas, sorgum dengan batang yang tinggi menghasilkan biji yang lebih besar pula (Andriani dan Isnaini 2013).

Hasil penelitian Hunter dan Anderson (1997) menunjukkan bahwa salah satu indikator yang menentukan tinggi rendah hasil biji sorgum adalah dimensi dan kerapatan malai. Pertumbuhan malai yang terganggu akan menurunkan tingkat produksi biji secara signifikan (Du Plessis 2008). Ukuran malai sorgum bervariasi dengan kisaran $4-50 \mathrm{~cm}$ dan lebar $2-20 \mathrm{~cm}$ (Dicko et al. 2006). Malai tanaman sorgum beragam, bergantung pada varietas dan dapat dibedakan berdasarkan posisi, kerapatan, dan bentuk. Varietas unggul sorgum yang digunakan dalam penelitian (Super 1 dan Super 2) termasuk dalam kategori kultivar sorgum bicolor yang dicirikan oleh tipe malai terbuka, bertangkai tegak, tandan pada bagian bawah lebih panjang dibandingkan pada bagian atas (Martin 1970). Varietas super 1 berdasarkan deskripsinya mempunyai panjang malai $26,7 \mathrm{~cm}$, bentuk malai lonjong dan kompak, serta kedudukan malai pada pucuk tanaman. Fase generatif/pembentukan malai merupakan fase yang sangat penting dalam budidaya sorgum karena terkait dengan banyaknya biji yang terbentuk.

Tabel 2. Tahapan penyaringan peubah yang masuk dalam model regresi berganda

\begin{tabular}{|c|c|c|c|c|c|}
\hline Penyaringan model & Jumlah kuadrat & $\mathrm{df}$ & Mean square & $\mathrm{F}$ & Sig \\
\hline \multicolumn{6}{|l|}{$\begin{array}{l}\text { Model I } \\
\text { X3 = Lebar malai }\end{array}$} \\
\hline Regresi & 28,757 & 1 & 28,570 & 130,650 &, 000 \\
\hline Residual & 19,369 & 88 & ,220 & & \\
\hline Total & 48,127 & 89 & & & \\
\hline \multicolumn{6}{|l|}{$\begin{array}{l}\text { Model II } \\
\text { X3 = Lebar malai } \\
\text { X5 = Tingqi tanaman }\end{array}$} \\
\hline Regresi & 31,468 & 2 & 15,734 & 82,174 & ,000 \\
\hline Residual & 16,658 & 87 & 0,191 & & \\
\hline Total & 48,127 & 89 & & & \\
\hline \multicolumn{6}{|l|}{$\begin{array}{l}\text { Model III } \\
\text { X3 = Lebar malai } \\
\text { X5 = Tinggi tanaman } \\
\text { X2 = Panjang malai }\end{array}$} \\
\hline Regresi & 32,653 & 3 & 10,884 & 60,491 & ,000 \\
\hline Residual & 15,474 & 86 & & & \\
\hline Total & 48,127 & 89 & & & \\
\hline
\end{tabular}


Tabel 3. Kinerja model pendugaan hasil sorgum

\begin{tabular}{lrrrrl}
\hline Model & \multicolumn{1}{l}{ R } & \multicolumn{1}{c}{ R- Square } & \multicolumn{1}{l}{ Adjusted R Square } & \multicolumn{1}{c}{ Standard error } & Keterangan \\
\hline Model I (X3) &, 773 &, 598 &, 593 &, 46916 & Sangat nyata \\
Model II (X3, X5) &, 809 &, 654 &, 646 &, 43758 & Sangat nyata \\
Model III (X3, X5, X2) &, 824 &, 678 &, 667 &, 42418 & Sangat nyata \\
\hline
\end{tabular}

Pada model regresi bertatar, selain dimensi malai, tinggi tanaman yang juga berpengaruh terhadap tingkat capaian hasil biji sorgum adalah tinggi tanaman. Varietas Super 1 mempunyai tinggi tanaman berkisar 210-220 cm sedangkan varietas Super 2 tingginya dapat mencapai $230 \mathrm{~cm}$. Kedua varietas ini selain diarahkan untuk produksi biji, batang tanaman dapat diekstrak niranya untuk dijadikan sumber bioetanol (Pabendon et al. 2012). Kaplan dan Rukiye (2014) melaporkan adanya hubungan yang erat antara tinggi tanaman dengan biomas berdasarkan indikator laju fotosintesis, konduktansi stomata serta kandungan klorofil daun yang secara tidak langsung berpengaruh terhadap tingkat hasil biji yang diperoleh.

Kombinasi penyaringan tinggi tanaman dan dimensi malai secara bertatar serta uji kesesuaian input/masukan model menggunakan uji multikolinearitas berhasil mengurangi jumlah variabel input model masing-masing sebanyak tiga input variabel pada uji multikolinearitas, serta empat input variabel pada uji regresi bertatar. Model akhir regresi hubungan tinggi tanaman dan dimensi malai berkontribusi terhadap produksi biji. Hasil penyaringan bertatar berdasarkan Tabel 4 diperoleh persamaan regresi linier berganda sebagai berikut:

$$
Y=-3,413+0,033 \times 2+0,561 \times 3+0,006 \times 5
$$

Hasil uji regresi linier berganda menunjukkan bahwa setiap kenaikan 1 (satu) nilai variabel panjang malai akan menaikkan produksi sorgum sebesar 0,033 ton. Kenaikan 1 (satu) nilai variabel lebar malai akan menaikkan produksi sorgum sebesar 0,5 ton sedangkan kenaikan 1 (satu) nilai variabel tinggi tanaman akan menaikkan produksi sorgum sebesar 0,06 ton.

Gambar 3 memperlihatkan diagram skater dari data aktual tingkat hasil sorgum serta nilai prediksi hasil menggunakan model regresi penyaringan bertatar. Pada setiap diagram, nilai ramalan yang baik akan berada pada garis dengan kemiringan $45^{\circ}$. Hasil pengamatan menunjukkan bahwa model dapat memprediksi hasil dengan baik dengan nilai koefisien determinasi $=0,68$ serta koefisien korelasi $=0,82$. Namun demikian, model mengalami sejumlah overestimate hasil pada beberapa titik pengamatan. Hal ini diduga karena tingkat kesuburan tanah yang berbeda. Goldsworthy dan Fisher (1992), menyatakan penyediaan hara yang cukup khususnya hara makro seperti nitrogen akan berpengaruh terhadap jumlah biji dan selanjutnya mempengaruhi hasil. Tanaman yang mengalami kekurangan nitrogen pada periode awal pertumbuhannya menghasilkan malai kecil dengan cabang primer dan sekunder lebih sedikit, serta floret yang lebih sedikit pada kemunculan malai dibanding tanaman yang memiliki persediaan nitrogen yang cukup.

Korelasi sederhana antara peubah disajikan pada Tabel 5. Analisis sumber keragaman menunjukkan bahwa peubah bebas dari karakter fenotipik sorgum yang berkorelasi dan berpengaruh nyata terhadap hasil yaitu lebar malai $(r=0,773)$, tinggi tanaman saat panen $(r=0,672)$ serta panjang malai $(r=0,475)$. Variabel lain mempunyai pengaruh yang kecil terhadap hasil. Hasil ini sejalan dengan berbagai hasil penelitian sebelumnya diantaranya Sankarapandian (2000) yang menunjukkan adanya korelasi antara parameter tinggi tanaman dengan peningkatan biomas dan hasil tanaman sorgum. Hundekar et al. (2016) menyatakan adanya pengaruh langsung (direct effect) serta pengaruh tidak langsung (indirect effect) dari malai sorgum terhadap hasil serta memberikan kontribusi bagi peningkatan hasil sorgum. Umur panen juga memberikan pengaruh tidak langsung terhadap hasil melalui variabel panjang dan lebar malai. Oleh karena itu, seleksi galur untuk hasil biji tinggi hendaknya diarahkan pada bentuk malai yang panjang serta tipe malai yang kompak dengan memperhitungkan aspek pengaruh tak langsung dari parameter agronomi lainnya.

Tabel 4. Regresi linier berganda hubungan parameter fenotipik dengan hasil tanaman sorgum

\begin{tabular}{lcrrrrrr}
\hline \multirow{2}{*}{ Model } & \multicolumn{2}{c}{ Unstandardized Coefficients } & & & Standardized Coefficients & T & Sig \\
\cline { 2 - 3 } & \multicolumn{2}{c}{ Konstanta Std. error } & & & \\
\hline Konstanta & $-3,413$ &, 442 & $-7,715$ &, 000 \\
Panjang malai (X2) &, 033 &, 013 &, 173 & 2,565 &, 012 \\
Lebar malai (X3) &, 561 &, 083 &, 543 & 6,774 &, 000 \\
Tinggi tanaman (X5) &, 006 &, 002 &, 263 & 3,257 &, 002 \\
\hline
\end{tabular}


Tabel 5 Analisis korelasi tiga variabel sorgum terhadap hasil

\begin{tabular}{lcccc}
\hline Parameter & Panjang malai & Lebar malai & Tinggi tanaman panen & Hasil \\
\hline Panjang malai & 1 & & & \\
Lebar malai &, $370^{* *}$ & 1 & 1 & \\
Tinggi tanaman panen &, $385^{* *}$ &, $632^{* *}$ &, $672^{* *}$ & 1 \\
Hasil &, $475^{* *}$ &, $773^{*}$ & \\
\hline
\end{tabular}

Keterangan: *: nyata taraf $5 \%$; **: nyata taraf $1 \%$; Nilai kritis satu arah $(1$-tail 0,05$)= \pm 0,301$ Nilai kritis dua arah $(2$-tail 0,01$)= \pm 0,354$

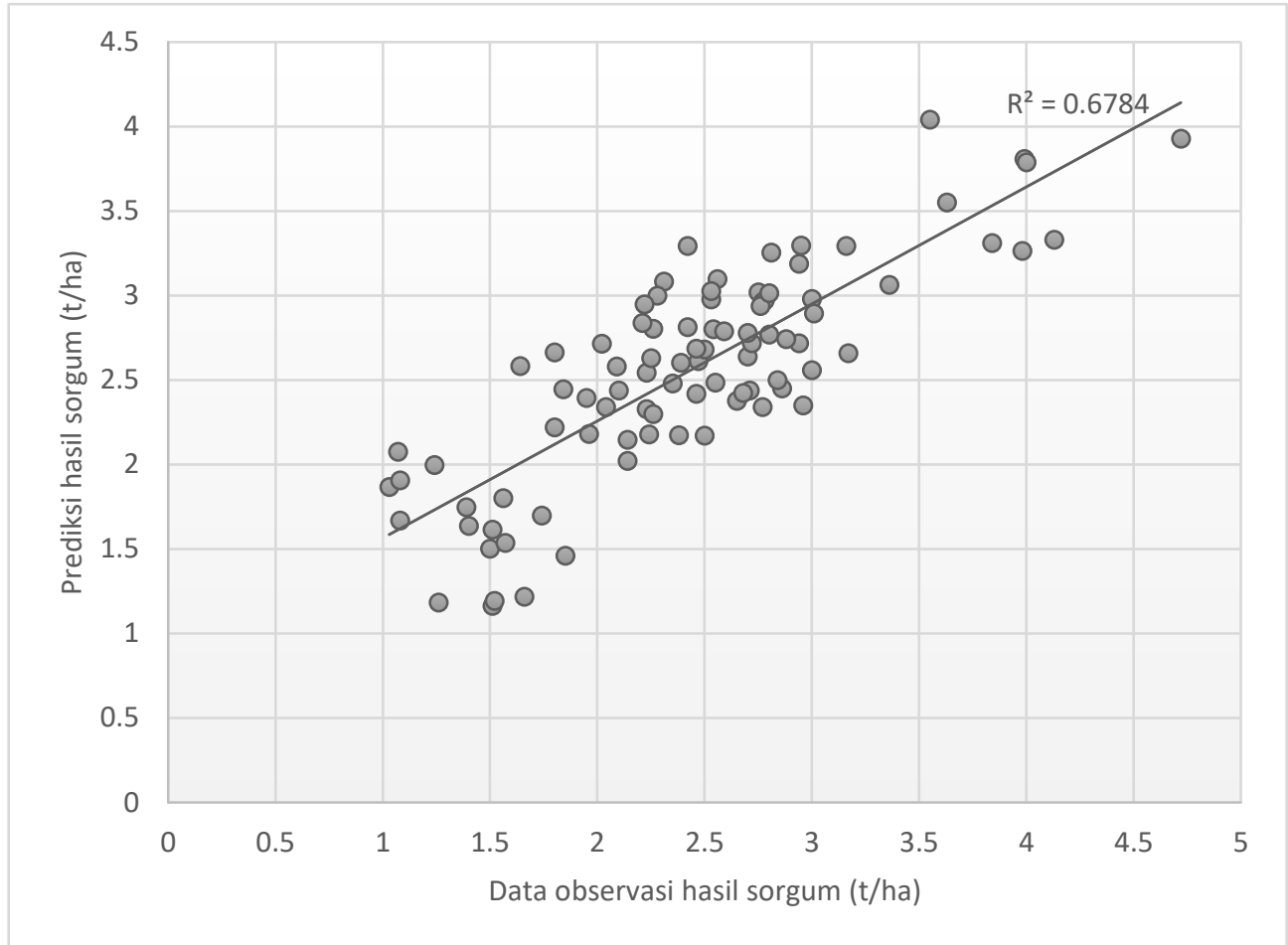

Gambar 3. Diagram skater tingkat hasil sorgum dan nilai prediksi hasil model regresi penyaringan bertatar

\section{KESIMPULAN}

Model regresi bertatar tinggi tanaman saat panen, lebar malai dan panjang malai merupakan peubah bebas yang optimal dalam produksi biji sorgum dengan nilai koefisien korelasi dan determinasi adalah 0,82 dan 0,68. Uji regresi linier kenaikan 1 (satu) nilai variabel: panjang malai menaikkan produksi 0,033 ton, lebar malai menaikkan produksi 0,5 ton dan tinggi tanaman menaikkan produksi 0,06 ton.

\section{DAFTAR PUSTAKA}

Akomo PO, Egli I, Okoth MW, Bahwere P, Cercamondi Cl, Zeder C, Njage PMK, Vo O. 2016. Estimated iron and zinc bioavailability in soybean-maize-sorghum ready to use foods: effect of soy protein concentrate and added phytase. J Food Process Technol. 7(2).

Andriani A., Isnaini M. 2013. Morfologi dan Fase Pertumbuhan Sorgum. In: Sorgum: Inovasi Teknologi dan Pengembangan. Jakarta: IAARD Press. Badan Penelitian dan Pengembangan Pertanian. Kementerian Pertanian. p. 47-68.
Aqil M, Bunyamin Z. 2013. Pengelolaan Air Tanaman Sorgum. Sorgum: Inovasi Teknologi dan Pengembangan. Bogor: Pusat Penelitian dan Pengembangan Tanaman Pangan. ISBN: 978-6021250-47-5. p.188-204.

Azrai M, Human S, Sunarti S. 2013. Pembentukan Varietas Unggul Sorgum untuk Pangan. Sorgum : Inovasi Teknologi dan Pengembangan. Bogor: Pusat Penelitian dan Pengembangan Tanaman Pangan. ISBN: 978-602-1250-47-5. p.107-137.

Balitsereal. 2017. Pedoman Teknis Budidaya Tanaman Sorgum. Unpublished.

Chatterjee S, Hadi AS. 2006. Regression Analysis by Example. Hoboken, NJ, USA: John Wiley \& Sons, Inc. (Wiley Series in Probability and Statistics). doi: 10.1002/0470055464.

Dicko MH, Gruppen H, Traoré AS, Voragen AGJ, Van Berkel WJH. 2006. Sorghum grain as human food in Africa: relevance of content of starch and amylase activities. African J Biotechnol. 5(5):384-395. 
Du Plessis J. 2008. Sorghum production. Republic of South Africa Department of Agriculture. https://www.nda.agric.za.

Fahrmeir L, Kneib T, Lang S, Marx B. 2013. Regression Models. In: Regression. Berlin, Heidelberg: Springer Berlin Heidelberg. p. 21-72. doi: 10.1007/978-3-64234333-9_2.

Farhood Al-salim SH, Saleh MM, ALbourky RHA, Abdulrahman AL. 2017. Correlation and regression analysis in sorghum under different levels of nitrogen. J Sci Agric. 1:69. doi:10.25081/jsa.2017.v1i0.31.

Goldsworthy PR, Fisher NM. 1992. Fisiologi Tanaman Budidaya Tropik. Tohari (Penerjemah).

Gomez KA, Gomez AA. 1984. Statistical procedures for agricultural research. 2nd ed. An IRRI Book. John Wiley \& Sons.

Hundekar MYR, Kamatar, Mallimar M, Brunda SM. 2016. Correlation and path analysis in rainy season sorghum [ Sorghum bicolour (L.) Moench]. Electron J Plant Breed. 7(3):666. doi:10.5958/0975928X.2016.00085.5.

Hunter EL, Anderson IC. 1997. Sweet sorghum. Janick $\mathrm{J}$, editor. John Wiley \& Sons, Inc.

Kaplan M, Rukiye K. 2014. Sweet Sorghum (Sorghum bicolor L.) Yield Parameters as Affected by Physiological Characteristics. Erciyes Üniversitesi Fen Bilim Enstitüsü Fen Bilim Derg. 30(2):115-122.

Keith TZ. 2014. Multiple Regression and Beyond: An Introduction to Multiple Regression and Structural Equation Modeling. 2nd ed. Routledge Pub, Taylor and Francis New York.

Kementerian Pertanian. 2020. Perencanaan Pembangunan Pertanian Tahun 2021. Jakarta.
Martin JH. 1970. History and classification of sorghum Sorghum bicolor (Linn.) Moench. Sorghum Prod Util.:1-27.

Mokashi DD, Jadhav JD, Khadatare S V, Deshpande AN. 2008. Crop weather relationship in rabi sorghum. Int J Agric Sci. 4(1):138-141.

Pabendon MB, Mas' ud S, Sarungallo RS, Nur A. 2012. Penampilan fenotipik dan stabilitas sorgum manis untuk bahan baku bioetanol. J Penelit Pertan Tanam Pangan. 30(1):60-69.

Park HM. 2003. Multicollinearity in regression models. Jeeshim and KUCC625.

Sankarapandian R. 2000. Correlation and path analysis of quantity and quality traits of fodder sorghum hybrids and their parents. Andhra Agric $\mathrm{J}$ (India). 47:191-196.

Shoaa Hosseini M, Khorasani SK, Farsi M. 2008. Study effects of water deficit stress on yield and yield components in some maize hybrids using path analysis. J Agric Sci. 18:71-85.

Stone LR, Schlegel AJ. 2006. Yield-Water Supply Relationships of Grain Sorghum and Winter Wheat. Agron J. 98(5):1359-1366. doi:10.2134/agronj2006.0042.

Tesso T, Tirfessa A, Mohammed H. 2011. Association between morphological traits and yield components in the durra sorghums of Ethiopia. Hereditas. 148(3):98-109. doi:10.1111/j.16015223.2011.02229.x.

Weisberg S. 2013. Applied Linear Regression 4th Edition. Wiley. School of Statistics University of Minnesota Minneapolis, MN. Canada. 